\title{
Spirituality: What Does it Mean and to Whom?
}

\author{
BRIAN STEENSLAND \\ Department of Sociology \\ Indiana University-Purdue University Indianapolis
}

\author{
XIAOYUN WANG \\ Lilly Family School of Philanthropy \\ Indiana University-Purdue University Indianapolis
}

\author{
LAUREN CHISM SCHMIDT \\ Center for the Study of Religion and American Culture \\ Indiana University-Purdue University Indianapolis
}

\begin{abstract}
While there is increasing interest in the topic of spirituality, scholars have limited data on its meaning among ordinary Americans. Based on an open-ended question in a new nationally representative survey, this paper documents the elements that make up people's views of spirituality. We find that theism is the dominant focus of American spirituality, with a relatively small percentage of people offering exclusively immanent descriptions. Cognitive and relational orientations are more prominent than behavioral or ethical orientations. Using latent class analysis, we identify seven distinctive views of spirituality that vary considerably in their
\end{abstract}

This is the author's manuscript of the article published in final edited form as:

Steensland, B., Wang, X., \& Schmidt, L. C. (2018). Spirituality: What Does it Mean and to Whom? Journal for the Scientific Study of Religion, 57(3), 450-472. https://doi.org/10.1111/jssr.12534 
prevalence and social profiles. Binary logit regression shows that spiritual self-identification, belief in God, and worship attendance are the religious factors most strongly associated with views of spirituality. Among socio-demographic predictors, significant associations with gender, race, education, and income are limited or absent. In contrast, the influences of age and political ideology are more substantial.

Keywords: spirituality, meaning, survey, American

Acknowledgements: We are grateful to our colleagues at the Center for the Study of Religion and American Culture at IUPUI who provided continuing support and feedback on this project: Philip Goff, Art Farnsley, Peter Thuesen, Joseph Tucker Edmonds, Amanda Friesen, and Ray Haberski. Special acknowledgement is due to Phil, who served as a co-investigator on the Research Support Funds Grant from IUPUI that provided funding for data collection and analysis. For advice and commentary at various stages, we also thank Robert Wuthnow, Nancy Ammerman, audiences at the Association for the Sociology of Religion annual meeting and the Pew Research Center, and three anonymous reviewers.

Correspondence should be addressed to Brian Steensland, Department of Sociology, Cavanaugh Hall \#303,425 University Boulevard, Indianapolis, Indiana, 46202.E-Mail: bsteens@iupui.edu. 
THE MEANING OF SPIRITUALITY AMONG AMERICANS

\section{INTRODUCTION}

We are awash in discourse about spirituality. Scholars and lay people alike increasingly distinguish between "spirituality" and "religion," with the former connoting an individual's pursuit of the sacred and meaningful, and the later connoting the communal and codified aspects of religious institutions. While the "spiritual" and "religious" were typically seen as coterminous in the past, they are now seen as distinct and sometimes at odds. Since the 1960s, there has been a trend toward spiritual seeking and away from religious commitment (Wuthnow 1998; Roof 1999). Scholars contend that a "spiritual revolution" is underway in western society (Heelas and Woodhead 2005). Manifestations of these trends in the U.S. include the growing percentage of Americans who identify as "spiritual but not religious" (Mercadante 2014) and public interest in alternative outlets for spiritual development through practices such as yoga and meditation.

So what does spirituality mean in the public mind? On this question our knowledge is advancing but still limited. Large national surveys are a major source of how we come to understand the contours of American religious life (Wuthnow 2015). If they address spirituality at all, they typically ask about interest in or identification with generic "spirituality." As Smith (2009) has observed, the rising identification with spirituality that is indexed in national surveys begs a host of further questions, since the meaning of "spirituality" or being a "spiritual person" is indeterminate. It can encompass traditional Christian belief, syncretic religious practices, appreciation of natural beauty, or reflection on life's meaning. Surveys containing more detailed or qualitative measures are better situated to capture these differences, but they have been based on smaller, non-representative samples that tell us about conceptions of spirituality among a particular population, such as social workers or older Americans. In-depth, qualitative 
examinations based on interviews (Mercadante 2014) or mixed data sources (Ammerman 2014) generate valuable conceptual contributions and convey the textures of lived spirituality, yet do not necessarily offer a basis for attributing patterns to the broader population.

This paper builds on the concepts and findings in existing studies but fills a gap that remains. It analyzes qualitative responses to a survey question about the meaning of spirituality in a nationally representative sample of more than 1000 people. We code the elements of spirituality contained in the responses and provide an overview of the characteristics people associate with spirituality. We then use latent class analysis to identify classes of people who share similar views of spirituality and describe the sociological profile of each class. Finally, we examine the religious and socio-demographic predictors of class membership. As scholars have argued, far from being individualistic, spirituality is patterned by sociological forces (e.g., Aupers and Houtman 2006; Ammerman 2013).

The paper offers a few contributions. It documents the meanings of spirituality among contemporary Americans, thus providing essential context for interpreting the upwelling identification with and interest in "spirituality." The variation we document should lend caution to general statements that imply a unitary meaning of the term; however, we do find central and peripheral connotations, and patterns that both confirm and differ from findings in other studies. Our ability to link different connotations of spirituality to particular demographic groups and social characteristics offers an advance that can increase our confidence when interpreting patterns and trends in the population. Because European scholars have conducted the most methodologically similar studies, we can also evaluate how common or exceptional American 
views of spirituality are when compared to those abroad. Based on our findings, we conclude with recommendations for improving instrumentation in studies of spirituality.

\section{RESEARCH ON CONTEMPORARY AMERICAN SPIRITUALITY}

Scholarly interest in spirituality increased during the 1990s. Prior to that period, studies of spirituality in America generally focused on "new age" or esoteric forms of spirituality among a bohemian or cosmopolitan minority. The publication of Wuthnow's (1998) After Heaven and Roof's (1999) Spiritual Marketplace marked a shift in focus toward the study of spirituality in society at large. Influenced by the ethos of the 1960s, the authors contended, the Baby Boom generation carried the values of individualism, authenticity, and seeking into mainstream American religious life, resulting in a distinction — among scholars and lay people alikebetween one's personal spiritual journey on one hand and institutional religion on the other. While for previous generations spiritual development, such as it was, took place within a religious context, it increasingly developed outside religious institutions, often to the exclusion of religious belonging altogether. Spiritual seeking was seen as authentic and positive; organized religion was viewed more skeptically.

So what do we know about what spirituality means to people today? A central source of information about contemporary American spirituality has come from large-scale surveys. The General Social Survey and surveys by the Pew Research Center indicate that 65 percent of Americans consider themselves very or moderately spiritual, and that an increasing number of Americans - 27 percent in 2017-consider themselves "spiritual but not religious" (Pew Research Center 2017). These surveys, like most national ones — such as the Baylor Religion 
Survey (Baker and Smith 2009)—contain mainly ordinal response choices assessing levels of spiritual self-identification, interest in spirituality, and the importance of spirituality in one's life. Some surveys also ask about spiritual experience, such as whether a respondent has experienced a sense of spiritual peace or wonder, or had a powerful spiritual moment in worship (Smith 2009; Pew Research Center 2014). These survey measures reference a generic "spirituality" in their question wording. So while they provide insight into patterns of interest, identification, importance, and experience within the population, what the respondent has in mind when they respond is not clear.

Studies based on more detailed or qualitative approaches are better situated to capture the specific meanings associated with spirituality. Research along these lines has focused on the relationship between religion and spirituality and therefore documented the meanings associated with both. Yet as Gall et al. (2011) have observed, these studies are few in number and based on relatively small and non-representative samples that limit the ability to generalize to the public at large. The studies nevertheless offer conceptual guidance for coding and analyzing descriptions of spirituality and a basis for comparing the frequencies of various meanings.

One approach to coding qualitative responses is to identify prominent themes or associations. Hodge and McGrew (2006) found nine different associations based on a sample of 303 graduate students in social work. Gall et al. (2011) identified seven meanings based on a survey of 234 people in a convenience sample. The most recent and in-depth study is Ammerman's (2013) mixed-methods analysis of 95 people in a quota-based sample. She identified eleven general themes, which she consolidated into four more encompassing packages. Implicit in Ammerman's study, and more explicit in others, is a second approach that codes 
descriptions of spirituality based on two analytic dimensions. In a study of 346 respondents, Zinnbauer et al. (1997) distinguished between the nature of the sacred (e.g., God, transcendent reality) and the content of spirituality (e.g., beliefs, practices, values, experiences). Schlehofer, Omoto, and Adelman (2008), based on a sample of 64 older adults in retirement communities, coded responses based on concept of the sacred or non-sacred and search for the sacred. What both the thematic and dimensional approaches share is their recognition that views of spirituality typically contain points of reference (God, higher power, nature, self, etc.) and orientations (cognitive, behavioral, relational, etc.), and that these are analytically and empirically distinct dimensions of spirituality. Our analytic approach follows from these insights and codes descriptions of spirituality according to their referent and orientation. Using two dimensions allows us to register the difference, for instance, between spirituality as described as belief in God, practices oriented toward God, or relationship with God. These distinct views of spirituality, while all referencing God, have different orientations and potentially differ among religious groups, such as between Catholics and evangelical Protestants (see, e.g., Luhrmann 2012). There is not a one-to-one relationship between type of reference and type of orientation. Using the two dimensions allows us to inductively identify affinities in the data.

A minority of qualitative studies document the frequencies associated with different meanings of spirituality. At a descriptive level, this is an important contribution that research on American spirituality can make, yet there is considerable variation in findings, which likely reflects differences in coding schemes, analytic decisions (e.g., whether coding categories are mutually exclusive), and underlying samples. Concerning the dominant focus of spirituality, for instance, Zinnbauer et al. (1997) found references to God or a higher power to be the most 
prevalent. Hodge and McGrew (2006) found a "personally constructed" view of spirituality focusing on the self to be most prevalent, followed by belief in a higher power. Ammerman (2013) found references to religious traditions, ethical frameworks, and God to be three prominent themes. Taken collectively, studies suggest that theism of some variety is the most prevalent referent of spirituality, but the degree of this prevalence and the distribution of other views is less clear.

Beyond the substantive meaning of spirituality, we look at the relationship between spirituality and religion. This has been a driving question in recent research. Commentators have cautioned that spirituality and religion should not be viewed as overly polarized; the two still overlap considerably for many people (Zinnbauer, Pargament, and Scott 1999). Some scholars further caution that the relationship between spirituality and religion should not be viewed in zero-sum terms. In some societal contexts, spirituality may be supplanting religion. In their comprehensive study of an English town, for instance, Heelas and Woodhead (2005) find evidence that a "holistic" spirituality—marked by individualism and subjectivism, and focused on the body and this-worldly practices - has largely replaced organized religion as a locus of spirituality. Yet in the U.S., evidence suggests that the connection between spirituality and religion may be better characterized as a "both/and" rather than an "either/or" relationship (e.g., Marler and Hadaway 2002). A question that we therefore examine is how much the term "spirituality" is associated with religion when people are not prompted to consider it. Ammerman (2013), for instance, finds that spirituality is frequently associated with organized religion, either positively or negatively, whereas Hodge and McGrew (2006) find spirituality defined in relation to religion in only three percent of their sample. 
Some of the closest studies methodologically to ours have been conducted in Europe, which allows an opportunity for evaluating cross-national similarities and differences. Berghuijs, Pieper, and Bakker (2013) fielded a study among a representative Dutch sample that asked respondents an open-ended question about how they understand spirituality and coded their responses in a similar ways to ours. Palmisano (2010) posed a question about spirituality almost identical to our own and had a representative sample of Italians choose from a list of options that mirror our coding scheme. Such comparisons can give us points of reference for evaluating the extent to which American spirituality is consonant with or discrepant from broader patterns in the modern West, particularly concerning the degree to which spirituality is focused on the transcendent or the immanent (Heelas and Woodhead 2005).

\section{Correlates of Spirituality}

While spirituality is commonly understood as being personal and having an individual locus, studies have found it to be sociologically patterned. These patterns are better documented in studies that examine levels of spirituality than types of spirituality. As prominent exceptions, Ammerman (2013) found that education, age, race/ethnicity, religious tradition, and worship attendance were associated with varieties of theistic and non-theistic strains of spirituality. Hodge and McGrew (2006), on the other hand, examined the correlates of different meanings of spiritually and found no association with socio-demographic predictors, including age, gender, race/ethnicity, and religious tradition.

Among studies of degrees of spirituality, age and gender are the most well established correlates. Analyses vary in their measures and objectives, but research generally finds 
increasing levels of spirituality over the life course and higher levels among women (Wink and Dillon 2002; Garelli 2007; Brown et al. 2012). Marler and Hadaway (2002) found that younger age cohorts are more likely to be spiritual than religious. Regarding racial patterns, non-whites are generally found to exhibit higher levels of spirituality (Jagers and Smith 1996), but there are weaker expectations regarding qualitative differences. Ammerman (2013), for instance, finds that ethnicity is only sometimes associated with types of spirituality. Education and income have been shown to affect levels of spirituality (Zinnbauer et al. 1997), but there has been little inquiry into how they may shape substantive views. A recent study of the "spiritual but not religious" (based on self-identified levels) suggests that people in this category are more likely to be younger, white, female, and have higher educational and income levels (Pew Research Center 2017). Qualitative studies suggest that people in this category have a more non-theistic, expansive, and relational view of spirituality (Mercadante 2014).

The Pew analysis points to an additional factor that may be associated with spirituality: political orientation. The gap among those who identify as "spiritual but not religious" is wider between Democrats and Republicans than it is between men and women or blacks and whites. The degree to which political ideology is systematically associated with views of spirituality has not been examined. The only study that includes a somewhat related analysis is Zinnbauer et al. (1997), which found that right-wing authoritarianism was statistically associated with spiritual and religious self-identity. Recent qualitative studies of the "nones" and "spiritual but not religious" do not explore the connections between political ideology and spirituality (Drescher 2016; Mercandante 2014). Better documented is the contemporary connection between political ideology and religious affiliation. Hout and Fischer (2014) provide evidence that politics and 
generational change are the two main drivers in the growing number of "nones" in recent years. Similarly, Putnam and Campbell report that political ideology shapes denominational affiliation and disaffiliation, not the other way around (Putnam and Campbell 2010; Campbell et al., forthcoming). Politically ideology could be associated with patterns of spirituality as well. In what follows, we present findings from a new nationally representative study that explores what the term spirituality means to people. The frequencies and latent classes we document address questions concerning the focus and nature of spirituality in the public mind and spirituality's relationship to organized religion. We then examine the relationship between meanings of spirituality and sociological predictors suggested by the literature.

\section{DATA AND METHODS}

The data for this analysis comes from an original, nationally representative online survey that explores spirituality and spiritual practice among Americans. The survey was fielded in May 2016 by GfK using their KnowledgePanel, a probability-based online panel of over 55,000 individuals designed to be representative of the general population of non-institutionalized adults age 18 and over residing in the United States. Using an equal probability selection method, the survey sample was drawn from the larger panel. The final sample size was 1038 and the response 
rate was 59 percent. ${ }^{1}$ Recent studies of American religion using surveys fielded by GfK include Beyerlein (2016), Edgell et al. (2016), and Scheitle and Ecklund (2017). ${ }^{2}$

The survey contained a range of questions about spirituality and spiritual practices. Our analysis focuses on the responses to an open-ended question that appeared at the beginning of the survey: "In a sentence or two, please describe what the term spirituality means to you." We coded the qualitative responses to this question in an iterative process that combined deductive and inductive approaches. Informed by analytic frameworks in the existing literature, and prior to reading the survey responses, we developed a coding instrument that captured two distinct dimensions of people's descriptions of spirituality: the referent of spirituality and the orientation toward that referent. After coding a portion of the sample in a preliminary phase, we revised the coding instrument by adding new categories and disambiguating existing categories that were overly broad. The final coding instrument contained thirteen elements in the referent dimension and six elements in the orientation dimension, each of which was coded as present or absent in a respondent's description. The elements for referent were monotheistic deity, higher being, supernatural phenomena, transcendence, the unknown, organized religion, juxtaposition to organized religion, non-religious authority, other people, self, natural world, the past, and the afterlife. The elements for orientation were cognitive, behavioral, ethical, emotional, relational,

\footnotetext{
${ }^{1}$ The characteristics of the unweighted sample approximate the geographical and demographic benchmarks found in the Current Population Survey. For added precision, we used the weights included in the dataset in all but the regression analyses.

${ }^{2}$ Further details on GfK's KnowledgePanel can be found here: http://www.gfk.com/products-az/us/knowledgepanel-united-states/
} 
and existential. The elements in each of the dimensions are distinct, but they are not mutually exclusive. People's descriptions of spirituality often included and combined multiple elements. Because we sought to capture the complexity of people's views, we coded all the elements that applied.

After we finalized the coding instrument, the third author coded the full set of responses. To maximize consistency across responses, she and the first author then developed decision rules for recurring descriptions of spirituality that straddled or combined elements. For instance, for descriptions of spirituality that centered on a Christian "born again" experience, we developed a decision rule that coded these responses as monotheistic deity and relational (rather than cognitive) based on the additional contextual information available in the five qualitative responses that used this term. Similarly, for responses that described spirituality in terms of the "golden rule," we developed a decision rule that coded these responses as other people, behavioral, and ethical since contextual information suggested these views of spirituality were oriented by commitment to action toward others rooted in general principles. If a respondent discussed the golden rule in tandem with their belief in God, the response would additionally be categorized as monotheistic deity and cognitive. After developing a set of decision rules in this iterative fashion, the first and third authors reviewed the coding for all the responses until there was agreement on each case.

In the Findings section, we present the frequencies of the nineteen items in order to provide a relatively unreduced overview of the elements that constitute Americans' views of spirituality. We also sought to distill these views of spirituality into a more reduced form. To do this we used latent class analysis, which identifies unobserved or latent classes that account for 
association among observed variables (Lazarsfeld and Henry 1968). To determine the number of latent classes, we followed the three selection criteria outlined by Collins and Lanza (2010): statistical criteria such as fit measures, the parsimony of the model, and the interpretability of the results. We used the Baysian Information Criterion (BIC) as the statistical criteria. BIC takes both parsimony and goodness-of-fit into account. After determining the number of latent classes, posterior membership probabilities estimate the likelihood that a respondent belongs to each class. Subsequently we assigned respondents to the class to which they had the highest likelihood of belonging. Following Pearce, Hardie, and Foster (2013), this person-centered approach allows us to identify the common sociological characteristics of people who hold similar views of spirituality and, further, examine the religious and socio-demographic factors that predict membership in one class rather than others (see also Kulis and Tsethlikai 2017).

To identify the sociological profiles of the latent classes and the predictors of class membership, we used variables identified as potentially relevant in the existing empirical literature on spirituality. Six variables measure aspects of religion and six variables measure socio-demographic characteristics. Table 1 provides details on the variables. For some sociodemographic measures, we use categorical variables for descriptive analysis and binary or continuous variables for the regression analysis. ${ }^{3}$

${ }^{3}$ We handled missing variables and "don't know" responses as follows: For the dependent variable, we dropped all observations with missing values $(\mathrm{N}=93)$. For independent variables, "don't know" responses and refusals were coded as 0 . We performed a robustness check that coded these responses as missing, thus dropping an additional 45 observations, and compared the 
THE MEANING OF SPIRITUALITY AMONG AMERICANS

[Insert Table 1 About Here]

FINDINGS

\section{The Elements of Spirituality}

Recent data on Americans' views of spirituality is limited, especially data based on open-ended questions that do not pre-structure the range of options. So we first present our findings in an unreduced form by describing the distribution of elements that constitute Americans' views of spirituality. Most descriptions of spirituality contained at least one referent element and one orientation element. Table 2 lists the frequency with which each element was mentioned.

[Insert Table 2 About Here]

Among the referents, a monotheistic deity was referenced in 41 percent of the responses. Respondents typically mentioned "God," "Jesus," or some other referent in the monotheistic faith traditions. ${ }^{4}$ The second most frequently mentioned referent, occurring in 22 percent of the responses, was an unnamed, typically singular, and often personified entity, most often a "higher power" or "supreme being," which we refer to collectively as higher being. After these two types of theistic referents, the prevalence of mentions to other referents dropped to the single digits. Eight percent of respondents associated spirituality with organized religion, most frequently "church" or being religious. Seven percent associated spirituality with a transcendent referent of some type, most often an unspecified reference to something bigger than the self and beyond the material world. Descriptors such as "bigger," "greater," "larger," and "above" were common. Six

results of the t-test and regression analyses. We did not find any significant differences. In order to retain as many variables as possible in the models, we coded the responses as 0 .

${ }^{4}$ There were no explicit references to deities in polytheistic religions in the survey responses. 
percent of respondents referenced the cultivation of self as the focus of spirituality, mentioning things like personal meaning, knowledge of self, self care, and following one's own path. Six percent of respondents mentioned non-theistic supernatural entities such as spirits, ghosts, angels, and the soul.

Five percent referenced other people as a focus of spirituality — most often a generalized reference to "others" or "other people" but also including references to family and friends. Five percent referenced the natural world, often in terms of "nature," "all creatures," or "the universe." Four percent defined spirituality in contrast to organized religion, usually without a further substantive description and sometimes with the connotation that spirituality is broader than religion. Four percent of responses contained references to an afterlife. Three percent of responses contained a reference to the unknown, the mysterious or the "beyond comprehension." In contrast to references to the transcendent, in which the respondents described themselves as aware of and often part of something larger, references to the unknown focused on things unknowable, unprovable, mysterious, and beyond the senses. Finally, two referents for which we created coding categories received little or no mention: the past (tradition, history, etc.) and nonreligious sources of authority.

The orientation of spirituality typically described the connection between the respondent and the referent(s). By far the most prevalent orientation was cognitive, which was mentioned in 58 percent of responses, usually in terms of belief, faith, or knowledge. Descriptions of a relational orientation occurred in 29 percent of the responses. This included things like a relationship with Jesus, guidance from a higher power, and connection to others. Sixteen percent of respondents referenced actions, such as praying to God, attendance at religious services, 
meditation, or adhering to a particular lifestyle. Seven percent of respondents mentioned an ethical dimension, such as living based on Biblical principles or a moral code. Another seven percent of respondents referenced an emotional dimension of spirituality, such as feelings of awe, joy, or gratitude. And three percent referenced an existential plane of spirituality having to do with being.

Nine percent of the respondents did not provide a description of spirituality. Of those, roughly half left the survey question blank and the other half wrote that they did not know what spirituality meant. Subsequent analysis showed that two variables, holding others constant, had a significant association with patterns of non-response. Respondents who described themselves as very or somewhat spiritual were more likely to provide a description of spirituality and respondents with no religious affiliation were less likely to provide a description.

\section{Classifying Views of Spirituality}

Our next goal was to determine how many commonly shared views of spirituality there are. For this we used latent class analysis, a person-centered approach, to examine the relationship between the elements of spirituality. To facilitate the analysis, we dropped some elements and combined others. We dropped the past because it did not show up, non-religious authority because it was mentioned only once, and the afterlife because it was mentioned infrequently and co-occurred with theism. We also dropped the "not religion" element. While it is valuable to assess the degree to which the "religion vs. spirituality" distinction orients people's views of spirituality (as we discuss later in the paper), the "not religion" element contains little substantive meaning beyond the juxtaposition itself. If respondents elaborated further, those elaborations are 
coded using the other variables. We combined the supernatural, transcendent, and unknown elements into a broader "something beyond" category due to their relatively low levels of frequency and because the distinction between transcendent and unknown elements - which we introduced inductively after a first round of coding — was sometimes challenging to maintain given the inexact language people used. We combined self, other people, and nature into a broader "immanent" category due to their lower levels of frequency and because they shared a "this-worldly" referent. We combined the existential and emotional elements to create an "experiential" category because the existential element was infrequent and because both the emotional and existential elements shared an experiential dimension that the text of the responses suggested were substantively similar.

To determine the optimal number of classes, we used a combination of statistical and substantive criteria. Using adjusted BIC as our fit statistic and the entropy R-squared statistic as the measure of how well individuals are assigned to classes, we determined that a seven class solution was optimal. As Table 3 shows, solutions with fewer than seven classes had worse scores for fit and assignment statistics. Equally as important, the seven class solution rendered substantively interpretable groupings. Solutions with more classes did not substantially improve model fit or probability of correct assignment, so the seven class solution proved to be the most parsimonious.

\section{[Insert Table 3 About Here]}

Each of the seven classes had an interpretable meaning based on the conditional probabilities that each element would constitute the basis of the class (see Table 4). Members of class 1 , who comprise 7 percent of the respondents, associate spirituality with organized religion, 
most typically in terms of being religious, belief in religious teachings, or attendance at worship services. ${ }^{5}$ Members of class 2, who comprise 21 percent of the respondents, associate spirituality with belief in God with a secondary emphasis on religious practices oriented to God, usually prayer. ${ }^{6}$ Members of class 3, who comprise 17 percent of the respondents, view spirituality as having a relationship with God with a secondary emphasis on belief. Members of class 4, who comprise 24 percent of the respondents, associate spirituality with belief in a higher being, sometimes using references to a higher power or supreme being and God interchangeably. Members of class 5, who comprise 13 percent of the respondents, define spirituality as belief in something beyond with a secondary relational emphasis. The referents of belief in these responses were multifaceted, including supernatural entities (spirits, ghosts, souls), something transcending individuals, and sources of mystery and wonder that are unknowable. Members of class 6, who comprise 12 percent of the respondents, view spirituality in terms of holistic connection. This is the most diffuse perspective on spirituality, with a primary focus on connections with and feelings toward self, nature, and other people, and a secondary focus on supernaturalism and transcendence. Finally, members of class 7, who comprise 5 percent of the

${ }^{5}$ Unless otherwise indicated, "respondents" from here forward refers to the 947 people who provided a substantive description of spirituality.

${ }^{6}$ Here and elsewhere to follow, the term "God" includes other specific theistic references, most often to Jesus. We use "God" because it was the most common and for ease of exposition in the text, but the terminology can be read to mean "monotheistic deity in the Abrahamic faith traditions." 
respondents, associate spirituality with ethical action with a prominent secondary theistic association with belief in God. This was most often expressed as some version of the golden rule.

[Insert Table 4 About Here]

\section{Classes and their Social Profiles}

Table 5 presents the religious and socio-demographic profiles of the classes. The table displays the mean or proportion for each correlate in a given class and reports whether deviation from the level in the rest of the sample is statistically significant based on t-tests. The results show that the classes have distinctive religious profiles and that most are distinctive in terms of age, education level, income, and political ideology. Notably, there are not significant gender- or race-based patterns associated with the class profiles. The information in the profiles allows for further interpretation of the classes and drawing connections to the scholarly literature.

[Insert Table 5 About Here]

\section{Spirituality as Organized Religion}

People who define spirituality in terms of organized religion are much less likely to consider themselves spiritual or attend church, and are more likely to be unaffiliated with a religious tradition. Thus this group appears to fit what Ammerman (2013) describes as a "belief and belonging" view of spirituality, where spirituality is associated with religious traditions and practices among those who are more distant from and perhaps disaffected by organized religion. ${ }^{7}$

\footnotetext{
${ }^{7}$ Ammerman (2013) refers to this a contested category because people holding this view evaluate spirituality both positively and negatively. The qualitative responses for this category in our data are more flatly descriptive than evaluative. However, there is little basis for interpreting this class as holding a positive view of spirituality.
} 


\section{Orientations Toward God}

The two classes with views of spirituality oriented toward God have different profiles. While both exhibit high mean levels on the religion and spirituality measures, the relationship with God class has uniformly higher levels than the belief in God class and is overrepresented by evangelical Protestants. This is consistent with Luhrmann's (2012) ethnographic account of evangelical practices and teachings that cultivate the experience of being in an intimate relationship with God. Catholics, in contrast, are significantly more likely to be in the belief in God class. The unaffiliated and the "spiritual but not religious" are underrepresented in both classes.

\section{Beliefs Outside Particular Traditions}

Two of the classes reference a view of spirituality based on belief in super-empirical realities other than a specific monotheistic deity. Both the belief in a higher being class and belief in something beyond class show consistently lower mean scores on the religion and spiritualty measures. Belief in a higher being exhibits a largely typical distribution of religious affiliation, indicating the diffuseness of this view of spirituality among people with moderate religious and spiritual engagement. The belief in something beyond class shows overrepresentation among Jewish respondents and the unaffiliated, and underrepresentation among evangelicals and Catholics.

\section{Relational Spirituality}

Two of the classes are based on a relational orientation to spirituality. Yet the relationship with God and holistic connection classes are mirror images of each other in a number of ways, having mean scores significantly above or below the mean, respectively, on 
corresponding items: religion measures, religious affiliation (evangelical Protestants and the unaffiliated) and the "spiritual but not religious." The classes also exhibit mirror image patterns across age cohorts, with the Gen-X generation being the inflection point of the generational shift away from relationship with God and toward holistic connection among younger people.

\section{Ethical Action}

A comparison across the seven classes shows that people who define spirituality in terms of ethical action are the least distinctive group. They are more likely to attend religious services - which reinforces the pattern in Table 4 that ethical action is often coupled with roots in a faith tradition — but are otherwise similar to the overall sample in terms of religion and spirituality measures. The only highly significant socio-demographic pattern is generational, with older people being considerably more likely to have this view of spirituality than millennials.

\section{Social Factors that Influence Spirituality}

Next we turn to a multiple regression analysis to examine the extent to which religious and socio-demographic correlates are associated with class membership holding other factors constant. Table 6 reports the odds ratios from binary logit regression models. Most of the variables are the same as those we used in Table 5, though age and income are continuous variables and education level is assessed with a binary variable measuring completion of a bachelor's degree. ${ }^{8}$ In preliminary analyses we entered the religion variables, socio-demographic

\footnotetext{
${ }^{8}$ In the measures for religious tradition, evangelical Protestant is the omitted category and the "Other" category, due to small group sizes, combines the RELTRAD categories for black
} 
variables, and political ideology variable in step-wise fashion. There were not large substantive differences between the results in the partial and complete models. So we present only the complete models here. We first discuss the religion variables and then turn to the sociodemographic measures.

\section{[Insert Table 6 About Here]}

Having a strong spiritual self-identity is the most pronounced religious predictor across the classes, decreasing the likelihood of defining spirituality in terms of organized religion, belief in a higher being, and ethical action, and increasing it for having a relationship with God. Belief in God has a strong association with views of spirituality. Consistent with intuition, it significantly increases the likelihood that spirituality is defined in terms of belief in God and relationship with God, and decreases the likelihood that it is defined as belief in something beyond. Weekly church attendance has a positive association with having a relationship with God and ethical action. Considering religion as important in one's life decreases the likelihood of defining spirituality as organized religion. The role of religious affiliation, once other religious influences are factored in, mainly manifests itself in terms of having a relationship with God. Evangelicals are more likely to view spirituality this way than are other religious groups. The religiously unaffiliated are more likely to define spirituality in terms of holistic connection. Respondents who are "spiritual but not religious" are more likely to define spirituality in terms

Protestant, Jew, and "other religions." Given this combination of categories, statistically significant patterns for Other do not yield a substantively meaningful interpretation. 
of holistic connection and ethical action, and less likely to see it as equivalent to organized religion. ${ }^{9}$

Turning to socio-demographic variables, we continue to see no distinctive difference regarding views of spirituality between women and men or whites and non-whites. While gender and race have both been shown to be associated with levels of spirituality, they are less clearly associated with types of spirituality. ${ }^{10}$ Two other factors — age and political ideology-have a stronger association. Age predicts class membership in five of seven cases. Being older is positively associated with belief in God, relationship with God, and viewing spirituality in terms of ethical action. It is negatively associated with belief in a higher being and holistic connection. Political ideology is associated with class membership in four cases. ${ }^{11}$ Liberals are less likely to

\footnotetext{
${ }^{9}$ The variable "spiritual but not religious" was created from the spiritual self-identity and importance of religion variables, which are also independent variables in our regression models.
} To check for collinearity among the three variables, we ran a regression model that included the "spiritual but not religious" variable but excluded the other two. Compared to the model with all three variables, the effects of "spiritual but not religious" did not change substantially, which indicates that there is not a collinearity problem when the three variables are included.

${ }^{10}$ For the analysis of race, we ran separate, supplementary models using binary variables for black and Hispanic rather than white. The alternative variables were insignificant with a few exceptions: The variable for black, holding black Protestant affiliation constant, was positively associated with "belief in a higher being" and "ethical action" and negatively associated with "relationship with God" (all p <.05).

${ }^{11}$ Given the pronounced influence of political ideology, we ran a number of robustness checks using other constructions of the variable to ensure that the effect was not an artifact of coding. 
view spirituality in terms of organized religion or belief in God, and more likely to view it in terms of belief in something beyond or holistic connection. The influences of education and income are more limited. Education is positively associated with belief in a higher being and negatively associated with defining spirituality as religion. Income is positively associated with seeing spirituality in terms of belief in something beyond.

\section{DISCUSSION}

With increased interest in spirituality comes the importance of better understanding its meanings and social correlates. Based on a new nationally representative survey, this paper describes the elements that make up people's views of spirituality, documents the size and social profile of classes who view spirituality in similar ways, and documents the sociological factors that shape people's views. We close by contextualizing these findings in light of other studies of spirituality and highlighting research areas for future consideration.

\section{The Elements of Spirituality}

Descriptions of spirituality from everyday Americans reveal a variegated though clearly structured pattern. Theism is the dominant referent of spirituality. Forty-one percent of descriptions referenced God and 21 percent contained some other type of reference to a higher being. A further 13 percent included references to transcendence or supernaturalism. In

Using political ideology as a seven-level ordinal variable and five-level ordinal variable resulted in statistically similar patterns. The only coding scheme that weakened the finding was including the "slightly liberal" response in a "Liberal" binary variable. 
supplementary analysis, we found that only nine percent of the responses described spirituality in exclusively immanent terms focused on self, other people, and/or the natural world. ${ }^{12}$ American spirituality, from the vantage point of personal views, is oriented toward theism and supernaturalism, though a fair portion of these views have points of reference that fall outside the purview of traditional religious doctrine.

The results shed light on the relationship between spirituality and religion in the American mind, which has been a central question in recent studies of spirituality. Fewer than four percent of respondents explicitly defined spirituality in juxtaposition to religion. This indicates that the "religion vs. spirituality" binary, which is prevalent among contemporary scholars of religion, does not provide inherent meaning to spirituality among lay people. Eight percent of respondents associate spirituality with aspects of institutional religion, such as attendance at worship services or "being religious." So twice as many people see religion and spirituality as overlapping than as juxtaposed. Yet the percentage of people with both views, taken together, is still small. Lay people on the whole see spirituality as distinct from religion but not as intrinsically defined in relation to it, either negatively or as coterminous.

\section{Classes of Spirituality}

The latent class analysis tells us about the distribution and social profiles of groups of people rather than the distribution of elements associated with spirituality. The majority of people - 62 percent - have views of spirituality focused on God or a higher being. Among those

\footnotetext{
12 The social profile of people holding this "exclusively immanent" view is similar to the profile of the holistic connection class.
} 
who view spirituality as centering on God specifically, there is a nearly even split between those whose orientation is cognitive or relational. The relational view, as its class profile shows, is associated with higher levels of spirituality and religiosity. Primarily immanent views are shaded with transcendence to different degrees. Among the 12 percent of people who associate spirituality with holistic connection to self, nature, and other people, one in five was likely to make a reference to a higher power or something beyond. Among the 5 percent of people who associated spirituality with ethical action, more than half also included a theistic reference to God or a higher power.

It is illustrative to compare the size of these groups to findings from roughly comparable studies, since existing studies, especially in the U.S., yield inconsistent findings. Ammerman's (2013) analysis is the most similar and the most recent. While her categories are not mutually exclusive (in contrast to our latent classes), the relative sizes of her categories provide valuable points of comparison. In her respondents' portrayals of spirituality, she finds that 71 percent of her sample employs a "theistic package," while 57 percent use an "extra-theistic package" and 75 percent employ an "ethical package." We find a theistic perspective, at 62 percent, to be the most prominent. If we approximate Ammerman's “extra-theistic package," which would include the "something beyond," holistic connection, and ethical action views, we find that roughly 30 percent of the sample holds a kindred view. Given the different coding schemes, these findings are broadly consistent with one another.

We see the clearest difference with Ammerman concerning the place of ethical commitments in the American spiritual imagination. Ammerman finds the ethical package to be widely used and broadly distributed. We find that it is diffuse, in the sense that there is little 
that's distinctive in the social profile of people oriented by an ethical spirituality. But it is also a distinctly minor way of describing spirituality. When asked about their views of spirituality, only seven percent of people included an ethical element in their response - and we were attentive to any response reflecting the "golden rule" or other ethical principles. Ammerman's data on each of her 95 respondents was much more extensive, so it may well be that deeper elicitation from our respondents would have yielded more ethical elements. But our data indicates that ethical principles are not a ready point of reference when people are asked to describe in a few sentences what spirituality means to them.

Studies from abroad provide a useful point of contrast as well. Berghuijs, Pieper, and Bakker (2013) conducted a very similar study — in terms of the qualitative measure, coding, and analysis - in a Dutch population. Like our study, they found that the cognitive ( 54 percent) and what they term "experiential" (28 percent) dimensions of spirituality were most prominent. Likewise, they found that the ethical referents only characterized a small percentage ( 7 percent) of their responses and that seven percent of their sample (compared to our 9 percent) did not know what spirituality meant. So the cross-national patterns are consonant in many ways. Yet in marked contrast to our findings, only 5 percent of their sample referenced belief in God or experience of God as the main content of their spirituality. Much more common were references to a transcendent reality, organized religion, the human mind, and social connectedness. This difference is similar to what we find when we compare our results to a recent Italian study, which found that spirituality as defined as belief in God is only the fifth most common view, even given the strong cultural influence of the Roman Catholic church in Italy. The four more 
common views focused on self, others, meaning, and morality (Palmisano 2010). ${ }^{13}$ So the differentiating feature of American spirituality when compared to spirituality among the Dutch and Italians is explicit theism. The "spiritual revolution" toward immanence in some European countries (Heelas and Woodhead 2005) finds less evidence in the U.S.

\section{Social Influences on Spirituality}

While an individual's view of spirituality feels personal, we find consistent evidence that perspectives on spirituality are socially patterned. People's conceptions of spirituality are not idiosyncratic; they flow from social location and experience. The seven classes of spirituality have distinctive social profiles. Analyses that situate spirituality in psychological but not sociological terms are fundamentally incomplete.

Among the factors identified in the existing literature that could influence spirituality, we found that a few stand out. Regarding religion, having a salient spiritual self-identity is the factor most frequently associated with different spiritual views. Few, if any, studies assess both level of spirituality and type of spirituality, so this association has gone unobserved. Some views are more or less likely to be held by people who see themselves as spiritual. Belief in God is a

\footnotetext{
${ }^{13}$ Interestingly, references to "purpose" or "meaning" came up fewer than 20 times in the
} sample. When they did, they often co-occurred with other referents (typically higher being), so we categorized them accordingly. Our suspicion is that spirituality in the American context retains theistic or supernatural connotations, so that people whose interior life is oriented largely by immanent purpose or meaning are more likely to be among the nine percent of respondents who did not provide a definition of spirituality because the term does not resonate with them. 
second significant influence. This is unsurprising once we recognize the centrality of theism as the most prominent referent in American spirituality. Attendance at worship services is associated with having a relationship with God and ethical action. When it comes to religious traditions, evangelical Protestants and the unaffiliated are the most distinctive, especially in seeing spirituality as having a relationship with God or as holistic connection. The "spiritual but not religious," while not a religious tradition, also exhibit distinctive views. They are much more likely to define spirituality in terms of holistic connection and ethical action, and much less likely, unsurprisingly, in terms of organized religion.

Among the socio-demographic factors, age is the most consistently influential. While this generally confirms the impact of age on spirituality that other studies have found, the outcome of interest here is different. Studies like Wink and Dillon's (2002) find a connection between age and degree of spirituality. We find a connection between age and type of spirituality. Younger people are considerably more likely to have non-theistic views, especially views that reflect what we call holistic connection. The social profiles indicate that the Gen-X generation is the inflection point in the age pattern. While it may be temping for some to interpret this pattern as a harbinger of the future, we cannot determine in this one study whether it reflects a generational or life-course dynamic. For instance, our evidence shows that Baby Boomers have more traditional views of spirituality than Roof (1999) found when they were younger. It is now millennials who are most distinctive. This suggests a life-course process at work. Whether millennials' views remain distinctive or whether they change as they age is an open question. What we can say with much greater certainty is that right now they are significantly more inclined toward the holistic connection view of spirituality. 
A novel association that we identify is between views of spirituality and political ideology. The association is more pronounced than for measures such as income, education, race, or gender. We cannot isolate cause and effect in our analysis, but we can take cues from recent work on political ideology and religious affiliation, which suggests that political commitments lead over time to sorting among religious (and secular) groups, not the other way around (Putnam and Campbell 2010; Hout and Fischer 2014; Campbell et al., forthcoming). The impact of political ideology on spirituality could also hold. Yet the causal influence could run the other way as well. Spiritual views rooted in theism, for instance, could incline people toward a political ideology more associated in the public mind with a commitment to transcendent authority (Haidt 2012). Further research is needed on this relationship. Whichever way the influence runs, the association leads to two further observations. First, it suggests that "spirituality" has its own internal ideological valences. While spirituality (in contrast to religion) generally has positive connotations (e.g., Hill et al. 2000; Gall et al. 2011), specific types of spirituality have different political associations, which may bear on the degree to which spirituality continues to carry a positive connotation. Second, it shows how thoroughly political polarization has saturated American life. Not only is there a "religion gap" when it comes to connections between political ideology and organized religion (Green 2010), there appears to be a "spirituality gap" as well.

The different views of spirituality identified in the paper suggest a number of further avenues for research. One recommendation is for research instruments that ask questions about generic spirituality to include an additional question, either closed- or open-ended, assessing what spirituality means to the respondent. This is relevant to established surveys such as the 
General Social Survey and those fielded by the Pew Research Center. It also pertains to recent innovative smartphone-based studies that track spiritual awareness across time and social context (e.g., Kucinskas et al. 2017). They leave the meaning of "spiritual" a largely open question. ${ }^{14}$ It would be illuminating to explore the connections between patterns of spiritual awareness and the definition of spirituality (e.g., theistic versus immanent) a respondent has in mind. Scholars should also consider replacing or augmenting the typical items that measure spiritual experience. For instance, questions that the Pew Research Center asks to assess substantive aspects of spirituality focus on feelings of peace, well-being, and wonder. Our study suggests that these sentiments are not often explicitly associated with spirituality, whereas feelings of connection (to God, the supernatural, other people) are much more common experiential associations. Questions about peace and wonder may be poor estimators of spiritual experience in the general public. Changes such as these, based on the patterns documented in our analysis, could advance the understanding of American spirituality.

\footnotetext{
14 The authors operationalize spiritual awareness with the question "I am aware of God at this moment" but direct respondents to substitute, if necessary, another word that stands for the divine or holy for them.
} 
THE MEANING OF SPIRITUALITY AMONG AMERICANS

\section{REFERENCES}

Ammerman, Nancy. 2013. Spiritual But Not Religious? Beyond Binary Choices in the Study of Religion. Journal for the Scientific Study of Religion 52(2):258-78.

Ammerman, Nancy. 2014. Sacred Stories, Spiritual Tribes: Finding Religion in Everyday Life. New York, NY: Oxford University Press.

Aupers, Stef and Dick Houtman. 2006. Beyond the Spiritual Supermarket: The Social and Public Significance of New Age Spirituality. Journal of Contemporary Religion 21(2):201-22.

Baker, Joseph and Buster Smith. 2009. None Too Simple: Examining Issues of Religious Nonbelief and Nonbelonging in the United States. Journal for the Scientific Study of Religion 48(4):719-33.

Berghuijs, Joantine, Jos Pieper and Cok Bakker. 2013. Conceptions of Spirituality among the Dutch Population. Archive for the Psychology of Religion 35:369-97.

Beyerlein, Kraig. 2016. The Effect of Religion on Blood Donation in the United States. Sociology of Religion 77(4):408-35.

Brown, I. Tucker, Tianzhi Chen, Nathan C. Gehlert and Ralph L. Piedmont. 2012. Age and Gender Effects on the Assessment of Spirituality and Religious Sentiments (ASPIRES) Scale: A Cross-sectional Analysis. Psychology of Religion and Spirituality 5(2):90-8.

Campbell, David E., Geoffrey C. Layman, John C. Green and Nathanael G. Sumaktoyo. Forthcoming. "Putting Politics First: The Impact of Politics on American Religious and Secular Orientations.” American Journal of Political Science.

Collins, Linda M. and Stephanie T. Lanza. 2010. Latent Class and Latent Transition Analysis: With Applications in the Social, Behavioral, and Health Sciences. Hoboken, NJ: Wiley. 
Edgell, Penny, Douglas Hartmann, Evan Stewart and Joseph Gerteis. 2016. Atheists and Other Cultural Outsiders: Moral Boundaries and the Non-religious in the United States. Social Forces 95(2):607-38.

Gall, Terry Lynn, Judith Malette and Manal Guirguis-Younger. 2011. Spirituality and Religiousness: A Diversity of Definitions. Journal of Spirituality in Mental Health $13: 158-81$

Garelli, Franco. 2007. Between Religion and Spirituality: New Perspectives in the Italian Religious Landscape. Review of Religious Research 48(3):318-26.

Green, John C. 2010. The Faith Factor: How Religion Influences American Elections. Washington, D.C.: Potomac Books.

Haidt, Jonathan. 2012. The Righteous Mind: Why Good People are Divided by Politics and Religion. New York, NY: Pantheon.

Heelas, Paul and Linda Woodhead. 2005. The Spiritual Revolution: Why Religion is Giving Way to Spirituality. Malden, MA: Blackwell.

Hill, Peter C., Kenneth I. Pargament, Ralph W. Hood, Jr, Michael E. McCullough, James P. Swyers, David B. Larson and Brian J. Zinnbauer. 2000. Conceptualizing Religion and Spirituality: Points of Commonality, Points of Departure. Journal for the Theory of Social Behavior 30(1):51-77.

Hodge, David R. and Charlene McGrew. 2006. Spirituality, Religion, and the Interrelationship: A Nationally Representative Study. Journal of Social Work Education 42(3):637-54. 
Hout, Michael and Claude Fischer. 2014. Explaining Why More Americans Have No Religious Preference: Political Backlash and Generational Succession, 1987-2012. Sociological Science 1:423-47.

Jagers, Robert J. and Paula Smith. 1996. Further Examination of the Spirituality Scale. Journal of Black Psychology 22(4):429-42.

Kucinskas, Jaime, Bradley R.E. Wright, D. Matthew Ray and John Ortberg. 2017. States of Spiritual Awareness by Time, Activity, and Social Interaction. Journal for the Scientific Study of Religion 56(2):418-437.

Kulis, Stephen S. and Monica Tsethlikai. 2017. Urban American Indian Youth Spirituality and Religion: A Latent Class Analysis. Journal for the Scientific Study of Religion 55(4):67797.

Lazarsfeld, Paul and Neil Henry. 1968. Latent Structure Analysis. Boston, MA: Houghton Mifflin.

Mercadante, Linda A. 2014. Belief without Borders: Inside the Minds of the Spiritual but not Religious. New York, NY: Oxford University Press.

Marler, Penny Long and C. Kirk Hadaway. 2002. "Being Religious" or "Being Spiritual” in America: A Zero-Sum Proposition. Journal for the Scientific Study of Religion 41(2):289300.

Palmisano, Stefania. 2010. Spirituality and Catholicism: The Italian Experience. Journal of Contemporary Religion 25(2):221-41. 
Pearce, Lisa D., Jessica Halliday Hardie and E. Michael Foster. 2013. A Person-Centered Examination of Adolescent Religiosity Using Latent Class Analysis. Journal for the Scientific Study of Religion 52(1):57-79.

Pew Research Center. 2015. "U.S. Public Becoming Less Religious.” Washington, D.C. Available at http://assets.pewresearch.org/wpcontent/uploads/sites/11/2015/11/201.11.03_RLS_II_full_report.pdf. Accessed June 4, 2018.

Pew Research Center. 2017. "More Americans Now Say They're Spiritual but not Religious." Washington, D.C. Available at http://www.pewresearch.org/fact-tank/2017/09/06/moreamericans-now-say-theyre-spiritual-but-not-religious/ft_17-09-05_spiritualnotreligious 310px/. Accessed June 4, 2018.

Putnam, Robert D. and David E. Campbell. 2010. American Grace: How Religion Divides and Unites Us. New York, NY: Simon and Schuster.

Roof, Wade Clark. 1999. Spiritual Marketplace: Baby Boomers and the Remaking of American Religion. Princeton, NJ: Princeton University Press.

Scheitle, Christopher P. and Elaine Howard Ecklund. 2017. Examining the Effects of Exposure to Religion in the Workplace on Perceptions of Religious Discrimination. Review of Religious Research 59(1):1-20.

Schlehofer, Michele M., Allen M. Omoto and Janice R. Adelman. 2008. How to 'Religion' and 'Spirituality' Differ? Lay Definitions in Older Adults. Journal for the Scientific Study of Religion 47(3):411-25.

Smith, Christian and Patricia Snell. 2009. Souls in Transition: The Religious and Spiritual Lives of Emerging Adults. New York, NY: Oxford University Press. 
Steensland, Brian, Jerry Z. Park, Mark D. Regnerus, Lynn D. Robinson, W. Bradford Wilcox and Robert D. Woodberry. 2000. The Measure of American Religion: Toward Improving the State of the Art. Social Forces 79(1):291-318.

Underwood, Lynn G. and Jeanne A. Teresi. 2002. The Daily Spiritual Experience Scale: Development, Theoretical Description, Reliability, Exploratory Factor Analysis, and Preliminary Construct Validity using Health-Related Data. Annals of Behavioral Medicine 24(1):22-33.

Wink, Paul and Michele Dillon. 2002. Spiritual Development Across the Adult Life Course: Findings from a Longitudinal Study. Journal of Adult Development 9(1):79-93.

Woodberry, Robert D., Jerry Z. Park, Lyman A. Kellstedt, Mark D. Regnerus and Brian Steensland. 2012. The Measure of American Religious Traditions: Theoretical and Measurement Considerations. Social Forces 91(1):65-73.

Wuthnow, Robert. 1998. After Heaven: Spirituality in America Since the 1950s. Berkeley and Los Angeles, CA: University of California Press.

Wuthnow, Robert. 2015. Inventing American Religion: Polls, Surveys, and the Tenuous Quest for a Nation's Faith. New York, NY: Oxford University Press.

Zinnbauer, Brian J., Kenneth I. Pargament, Brenda Cole, Mark S. Rye, Eric M. Butter, Timothy G. Belavich, Kathleen H. Hipp, Allie B. Scott and Jill L. Kadar. 1997. Religion and Spirituality: Unfuzzying the Fuzzy. Journal for the Scientific Study of Religion 36(4):549-64. 


\section{THE MEANING OF SPIRITUALITY AMONG AMERICANS}

Zinnbauer, Brian J., Kenneth I. Pargament and Allie B. Scott. 1999. The Emerging Meanings of Religiousness and Spirituality: Problems and Prospects. Journal of Personality 67(6):889-919. 
Table 1: Independent Variables $(\mathrm{N}=\mathbf{1 0 3 8})$

\begin{tabular}{|c|c|c|c|}
\hline Variables & Mean & Survey questions & Variable Values \\
\hline \multicolumn{4}{|l|}{ Religion Measures } \\
\hline Spiritual self-identification & .21 & $\begin{array}{l}\text { To what extent do you consider yourself a } \\
\text { spiritual person? }\end{array}$ & $\begin{array}{l}1=\text { very spiritual; } 0=\text { somewhat spiritual; not } \\
\text { too spiritual; not at all spiritual }\end{array}$ \\
\hline Importance of religion & .59 & How important is religion in your life? & $\begin{array}{l}1=\text { very important; somewhat important; } \\
0=\text { not too important; not at all important }\end{array}$ \\
\hline Belief in God & .69 & $\begin{array}{l}\text { Which statement comes closest to } \\
\text { expressing what you believe about God? }\end{array}$ & $\begin{array}{l}1=\text { I know God exists and have no doubts } \\
\text { about it; while I have some doubts, I do } \\
\text { believe in God; 0=I don't believe in a } \\
\text { personal God but I do believe in a higher } \\
\text { power of some kind; I don't know whether } \\
\text { there is a God, and I don't believe there is } \\
\text { any way to find out; I don't believe in } \\
\text { God; don't know }\end{array}$ \\
\hline \multicolumn{4}{|l|}{ Religious tradition } \\
\hline Evangelical Protestant & .24 & & \multirow{7}{*}{$\begin{array}{l}\text { Based on the classification method } \\
\text { developed by Steensland and colleagues } \\
\text { (Steensland et al. 2000; Woodberry et al. } \\
\text { 2012) }\end{array}$} \\
\hline Mainline Protestant & .14 & & \\
\hline Black Protestant & .05 & & \\
\hline Catholic & .21 & Religious affiliation and denomination & \\
\hline Jewish & .03 & & \\
\hline Other & .06 & & \\
\hline None & .27 & & \\
\hline Spiritual but not religious & .10 & & $\begin{array}{l}\text { Respondents were coded as } 1 \text { if they both } \\
\text { indicated "very spiritual" or "spiritual" on } \\
\text { the Spiritual self-identification variable } \\
\text { and a } 0 \text { on the binary Importance of } \\
\text { religion variable. }\end{array}$ \\
\hline
\end{tabular}




\section{Table 1: Summary Statistics (continued)}

\section{Socio-demographic measures}

Female

White

Generation

Silent

Baby Boomer

Gen-X

Millennial

\section{Education}

High school or less

Some college

Bachelor's degree or more

Household Income

Below $\$ 35,000$

$\$ 35,000-59,000$

$\$ 60,000-99,000$

$\$ 100,000$ or higher

Liberal
Race

Age

32

.42

.28

30

.27

.19

.23

.30

19

Highest degree received

Household income

We hear a lot of talk about liberals and conservatives in politics. Here is a sevenpoint scale on which the political views that people might hold are arranged from extremely liberal (1) to extremely

conservative (7). Where would you place yourself on this scale?
$1=$ female $; 0=$ male

$1=$ non-Hispanic white; $0=$ all other racial categories

Millennial (age 18-35), Generation X (age 36-51), Baby Boomer (age 52-70), and Silent Generation (age 71 and older)

$1=$ extremely liberal; liberal; $0=$ slightly liberal; moderate; slightly conservative; conservative; extremely conservative; don't know

Note: All means are weighted.

Refused and "don't know" are coded as 0. 
Table 2: Elements of Spirituality $(\mathbf{N}=\mathbf{1 0 3 8})$

\begin{tabular}{llrr}
\hline Dimension & Element & Frequency & Percentage \\
\hline Referent & Monotheistic deity & 425 & 41 \\
& Higher being & 224 & 22 \\
& Organized religion & 87 & 8 \\
& Transcendence & 71 & 7 \\
& Self & 66 & 6 \\
& Supernatural phenomena & 61 & 6 \\
& Other people & 52 & 5 \\
& Natural world & 47 & 5 \\
& Juxtaposition to organized religion & 38 & 4 \\
& Afterlife & 38 & 4 \\
& The unknown & 35 & 3 \\
& Non-religious authority & 1 & 0 \\
& Past & 0 & 0 \\
\hline Orientation & Cognitive & 600 & 58 \\
& Relational & 301 & 29 \\
& Behavioral & 166 & 16 \\
& Ethical & 76 & 7 \\
& Emotional & 71 & 7 \\
& Existential & 35 & 3 \\
\hline No response & Don't know & 50 & 5 \\
& No response & 43 & 4 \\
\hline
\end{tabular}

Note: All frequencies and percentages are weighted. 
Table 3: Fit Statistics for Latent Class Models

\begin{tabular}{cccc}
\hline Number of classes & BIC & Adjusted BIC & Entropy $R$-squared \\
\hline 2 & 1615.07 & 1548.38 & .72 \\
3 & 1356.65 & 1255.02 & .81 \\
4 & 1263.63 & 1127.06 & .82 \\
5 & 1239.31 & 1067.81 & .85 \\
6 & 1149.77 & 943.33 & .89 \\
$\mathbf{7}$ & $\mathbf{1 0 0 1 . 6 1}$ & $\mathbf{7 6 0 . 2 4}$ & .91 \\
8 & 1231.02 & 954.71 & .91 \\
9 & 1064.37 & 753.13 & .91 \\
10 & 1103.72 & 757.54 & .93 \\
\hline
\end{tabular}

Note: Lower BIC statistics indicate better model fit.

Higher Entropy R-squared indicates better class assignment.

Bold text indicates the preferred model. 
Table 4: Conditional Probabilities for the Elements of Spirituality in Seven Classes ( $N=947)$

\begin{tabular}{|c|c|c|c|c|c|c|c|}
\hline & $\begin{array}{l}\text { Organized } \\
\text { religion }\end{array}$ & $\begin{array}{l}\text { Belief in } \\
\text { God }\end{array}$ & $\begin{array}{l}\text { Relationship } \\
\text { with God }\end{array}$ & $\begin{array}{l}\text { Belief in a } \\
\text { higher } \\
\text { being }\end{array}$ & $\begin{array}{l}\text { Belief in } \\
\text { something } \\
\text { beyond }\end{array}$ & $\begin{array}{l}\text { Holistic } \\
\text { connection }\end{array}$ & $\begin{array}{l}\text { Ethical } \\
\text { action }\end{array}$ \\
\hline Monotheistic deity & .05 & 1.00 & 1.00 & .14 & .08 & .07 & .46 \\
\hline Higher being & .02 & .00 & .05 & .81 & .02 & .21 & .10 \\
\hline Something beyond & .00 & .00 & .01 & .07 & 1.00 & .23 & .04 \\
\hline Organized religion & .89 & .08 & .04 & .00 & .02 & .04 & .06 \\
\hline Immanent & .03 & .00 & .06 & .02 & .03 & .64 & .78 \\
\hline Cognitive & .33 & .91 & .32 & .97 & .78 & .18 & .49 \\
\hline Behavioral & .38 & .26 & .16 & .05 & .03 & .09 & .88 \\
\hline Ethical & .02 & .03 & .04 & .04 & .02 & .04 & .89 \\
\hline Experiential & .07 & .00 & .05 & .00 & .10 & .57 & .03 \\
\hline Relational & .00 & .00 & 1.00 & .11 & .17 & .65 & .22 \\
\hline $\mathrm{N}$ & 69 & 197 & 164 & 229 & 122 & 117 & 48 \\
\hline$\%$ of Sample & 7 & 21 & 17 & 24 & 13 & 12 & 5 \\
\hline
\end{tabular}

Notes: Some probabilities are listed as 0 or 1 due to rounding.

The "something beyond" category combines "supernatural," "transcendent," and "unknown" in Table 2.

The "immanent" category combines "self," "nature," and "community" in Table 2.

The "experiential" category combines "existential" and "emotional" in Table 2. 
Table 5: Means or Proportions for Religion and Socio-demographic Correlates for Seven Latent Classes (t-tests)

\begin{tabular}{|c|c|c|c|c|c|c|c|c|}
\hline Variables & $\begin{array}{l}\text { Organized } \\
\text { religion }\end{array}$ & $\begin{array}{l}\text { Belief in } \\
\text { God }\end{array}$ & $\begin{array}{l}\text { Relationship } \\
\text { with God }\end{array}$ & $\begin{array}{l}\text { Belief in a } \\
\text { higher } \\
\text { being }\end{array}$ & $\begin{array}{l}\text { Belief in } \\
\text { something } \\
\text { beyond }\end{array}$ & $\begin{array}{l}\text { Holistic } \\
\text { connection }\end{array}$ & $\begin{array}{l}\text { Ethical } \\
\text { action }\end{array}$ & $\begin{array}{l}\text { Full } \\
\text { sample }\end{array}$ \\
\hline \multicolumn{9}{|l|}{ Religious measures } \\
\hline Self-spiritual identity & $.06 * * *$ & .26 & $.52 * * *$ & $.08 * * *$ & .17 & .18 & .18 & .22 \\
\hline Importance of religion & .49 & $.81 * * *$ & $.89 * * *$ & $.53 *$ & $.39 * * *$ & $.39 * * *$ & .71 & .62 \\
\hline $\begin{array}{l}\text { Believe in God } \\
\text { Worship service }\end{array}$ & .63 & $.89 * * *$ & $.96^{* * *}$ & $.63^{*}$ & $.43 * * *$ & $.52 * * *$ & .78 & .71 \\
\hline attendance & $.16^{* *}$ & $.37 * * *$ & $.57 * * *$ & $.19 * * *$ & $.15 * * *$ & $.12 * * *$ & $.40^{*}$ & .29 \\
\hline \multicolumn{9}{|l|}{ Religious affiliation } \\
\hline Evangelical & .16 & $.30^{*}$ & $.50 * * *$ & .21 & $.14 * * *$ & $.12 * * *$ & .30 & .26 \\
\hline Mainline Protestant & .15 & .17 & .10 & .14 & .18 & .11 & .20 & .15 \\
\hline Black Protestant & .04 & .05 & .06 & .06 & .04 & .03 & .06 & .05 \\
\hline Catholic & .19 & $.29 * *$ & .26 & .21 & $.12 * *$ & .17 & .22 & .22 \\
\hline Jewish & .01 & .01 & .01 & .03 & $.06 * *$ & .03 & .03 & .03 \\
\hline Other & .07 & .06 & .03 & .05 & .04 & $.13 * * *$ & .02 & .06 \\
\hline None & $.39 * *$ & $.11^{* * *}$ & $.04 * * *$ & .30 & $.43 * * *$ & $.40 * * *$ & .17 & .24 \\
\hline Spiritual but not religious & .04 & $.04 * * *$ & $.04 * * *$ & .08 & .13 & $.29 * * *$ & .15 & .10 \\
\hline \multicolumn{9}{|l|}{ Socio-demographic measures } \\
\hline Female & .50 & .51 & .56 & .53 & .52 & .50 & .59 & .53 \\
\hline White & .67 & .63 & .68 & .65 & .67 & .58 & .66 & .65 \\
\hline \multicolumn{9}{|l|}{ Generation } \\
\hline Millennial & .40 & $.22 * * *$ & $.21 * * *$ & .35 & .34 & $.48 * * *$ & $.18^{* *}$ & .31 \\
\hline Gen-X & $.11^{* *}$ & .26 & .22 & .28 & .28 & .26 & .21 & .25 \\
\hline Baby Boomer & .39 & .38 & $.42 * *$ & .31 & .31 & $.23 * *$ & .31 & .34 \\
\hline Silent & .10 & $.14^{*}$ & $.16^{* *}$ & $.06 * *$ & .06 & $.03 * *$ & $.30 * * *$ & .11 \\
\hline \multicolumn{9}{|l|}{ Education } \\
\hline High school or less & $.53^{*}$ & $.52 * * *$ & $.51 * *$ & $.26 * * *$ & $.25 * * *$ & .39 & .40 & .40 \\
\hline Some college & .32 & .26 & $.22 *$ & .32 & .34 & .31 & $.39 *$ & .29 \\
\hline Bachelor or more & $.15^{* *}$ & $.22 * *$ & .28 & $.41 * * *$ & $.41 * * *$ & .30 & .21 & .31 \\
\hline \multicolumn{9}{|l|}{ Household income } \\
\hline Below $\$ 35,000$ & .29 & .28 & $.34^{*}$ & $.21^{*}$ & $.18^{* *}$ & .31 & .28 & .27 \\
\hline
\end{tabular}




\begin{tabular}{|c|c|c|c|c|c|c|c|c|}
\hline$\$ 35,000-59,000$ & $.32 * *$ & .22 & .18 & .16 & .18 & $.11 * *$ & .20 & .19 \\
\hline$\$ 60,000-99,000$ & .19 & .21 & .19 & .28 & .21 & .23 & .32 & .23 \\
\hline$\$ 100,000$ and above & $.20^{*}$ & .29 & .28 & .35 & $.44 * * *$ & .35 & .20 & .32 \\
\hline Liberal & $.008 * *$ & $.10^{* * *}$ & $.12 * *$ & .21 & $.33 * * *$ & $.35 * * *$ & .14 & .19 \\
\hline
\end{tabular}

$* * * p<.01, * * p<.05, * p<.1$

Notes: "Full sample" refers to the 947 people who provided a substantive description of spirituality. 
Table 6: Odds Ratios for Binary Logit Regression of Views of Spirituality on Independent Variables (N=947)

\begin{tabular}{|c|c|c|c|c|c|c|c|}
\hline Variables & $\begin{array}{l}\text { Organized } \\
\text { religion }\end{array}$ & $\begin{array}{c}\text { Belief in } \\
\text { God }\end{array}$ & $\begin{array}{c}\text { Relationship } \\
\text { with God }\end{array}$ & $\begin{array}{c}\text { Belief in a } \\
\text { higher being }\end{array}$ & $\begin{array}{l}\text { Belief in } \\
\text { something } \\
\text { beyond }\end{array}$ & $\begin{array}{c}\text { Holistic } \\
\text { connection }\end{array}$ & $\begin{array}{l}\text { Ethical } \\
\text { action }\end{array}$ \\
\hline \multirow[t]{2}{*}{ Spiritual self-identity } & $.322 * *$ & 1.047 & $3.005 * * *$ & $.248 * * *$ & 1.298 & 1.049 & $.454^{*}$ \\
\hline & $(.180)$ & $(.213)$ & $(.609)$ & $(.0717)$ & $(.404)$ & $(.340)$ & $(.187)$ \\
\hline \multirow[t]{2}{*}{ Importance of religion } & $.502 *$ & 1.372 & 1.236 & .749 & .831 & 1.597 & 1.428 \\
\hline & $(.204)$ & $(.419)$ & $(.514)$ & (.199) & $(.294)$ & $(.606)$ & $(.824)$ \\
\hline \multirow[t]{2}{*}{ Belief in God } & 1.247 & $2.231 * *$ & $4.674 * * *$ & 1.064 & $.429 * * *$ & .618 & .566 \\
\hline & $(.512)$ & $(.745)$ & $(2.492)$ & $(.280)$ & $(.141)$ & $(.204)$ & $(.296)$ \\
\hline \multirow[t]{2}{*}{ Worship service attendance } & .711 & .919 & $1.618^{* *}$ & .749 & .676 & .595 & $1.897^{*}$ \\
\hline & $(.291)$ & $(.181)$ & $(.336)$ & $(.169)$ & $(.219)$ & $(.207)$ & $(.699)$ \\
\hline \multicolumn{8}{|c|}{ Religious affiliation (omitted: Evangelical Protestant) } \\
\hline \multirow[t]{2}{*}{ Mainline Protestant } & 1.844 & 1.286 & $.420 * * *$ & .776 & 1.680 & 1.935 & 1.157 \\
\hline & $(.847)$ & $(.318)$ & $(.119)$ & $(.215)$ & $(.598)$ & $(.823)$ & $(.510)$ \\
\hline \multirow[t]{2}{*}{ Catholic } & 1.516 & 1.357 & $.590 * *$ & 1.133 & .845 & 1.593 & .792 \\
\hline & $(.667)$ & $(.304)$ & $(.141)$ & $(.276)$ & $(.316)$ & $(.649)$ & $(.336)$ \\
\hline \multirow[t]{2}{*}{ Other } & 1.368 & 1.111 & $.497 * *$ & .962 & 1.158 & $3.297 * * *$ & .848 \\
\hline & $(.809)$ & $(.333)$ & $(.162)$ & $(.293)$ & $(.473)$ & $(1.356)$ & $(.456)$ \\
\hline \multirow[t]{2}{*}{ None } & 2.179 & .852 & $.384^{*}$ & .979 & 1.351 & $2.270 *$ & .572 \\
\hline & $(1.100)$ & $(.309)$ & $(.194)$ & $(.300)$ & $(.529)$ & $(.991)$ & $(.345)$ \\
\hline \multirow[t]{2}{*}{ Spiritual but not religious } & $.181 * *$ & .669 & .671 & .611 & 1.025 & $4.795 * * *$ & $3.198 * *$ \\
\hline & $(.137)$ & $(.284)$ & $(.368)$ & $(.192)$ & $(.344)$ & $(1.599)$ & $(1.739)$ \\
\hline \multirow[t]{2}{*}{ Female } & 1.056 & .767 & 1.188 & 1.012 & .915 & .996 & 1.338 \\
\hline & $(.291)$ & $(.131)$ & $(.228)$ & $(.167)$ & $(.192)$ & $(.226)$ & $(.417)$ \\
\hline \multirow[t]{2}{*}{ White } & 1.231 & 1.105 & .944 & .992 & .954 & .966 & .830 \\
\hline & $(.424)$ & $(.226)$ & $(.212)$ & $(.194)$ & $(.244)$ & $(.256)$ & $(.304)$ \\
\hline \multirow[t]{2}{*}{ Age } & .998 & $1.010^{*}$ & $1.010^{*}$ & $.990 * *$ & .998 & $.978 * * *$ & $1.021 * *$ \\
\hline & $(.00804)$ & $(.00515)$ & $(.00574)$ & $(.00481)$ & $(.00610)$ & $(.00660)$ & $(.00975)$ \\
\hline \multirow[t]{2}{*}{ Bachelor's degree } & $.377 * *$ & .759 & .882 & $2.036 * * *$ & 1.179 & .968 & .565 \\
\hline & $(.152)$ & $(.155)$ & $(.196)$ & $(.380)$ & $(.274)$ & $(.247)$ & $(.218)$ \\
\hline \multirow[t]{2}{*}{ Household income (thousands) } & .998 & .999 & .999 & 1.000 & $1.004 * *$ & .999 & 1.000 \\
\hline & $(.00272)$ & $(.00163)$ & $(.00184)$ & $(.00147)$ & $(.00178)$ & $(.00202)$ & $(.00288)$ \\
\hline \multirow[t]{2}{*}{ Liberal political ideology } & $.309 * *$ & $.510 * *$ & 1.368 & .847 & $1.564 *$ & $1.881 * *$ & .724 \\
\hline & $(.154)$ & (.149) & $(.401)$ & $(.182)$ & $(.378)$ & $(.487)$ & $(.327)$ \\
\hline
\end{tabular}




\section{Constant}

$.130 * * * \quad .0898 * * * \quad .0288 * * *$

$.177 * * *$

$.177 * * *$

$0243 * * *$

Note: $* * * \mathrm{p}<.01, * * \mathrm{p}<.05, * \mathrm{p}<.1$. Standard errors are in parentheses. 